\title{
The Quest for Therapy in Lower Zaire
}

Comparative Studies in Health Systems and Medical Care N U M B E R 1 
COMPARATIVE STUDIES OF HEALTH SYSTEMS AND MEDICAL CARE

General Editor

Charles Leslie, University of Delaware

Editorial Board

Fred DUnN, M.D., University of California, San Francisco

RENÉE Fox, University of Pennsylvania

Eliot Freidson, New York University

EDWARD MONTGOMERY, Washington University

Yasuo Otsuka, M.D., Yokohama City University Medical School

CARL E. TAYlor, M.D., The Johns Hopkins University

K. N. UduPA, M.S., F.R.C.S., Banaras Hindu University

PAUl UNSCHULD, University of Marburg 


\section{The Quest for Therapy in Lower Zaire}

J O H N M. J A N Z E N

with the collaboration of William Arkinstall, M.D.

Foreword by Charles Leslie

UNIVERSITY OF CALIFORNIA PRESS Berkeley · Los Angeles · London 
University of California Press Berkeley and Los Angeles, California University of California Press, Ltd. London, England Copyright $\odot 1978$ by

The Regents of the University of California I S B N 0-520-03295-0

Library of Congress Catalog Card Number: 76-19982

Printed in the United States of America 